\title{
SISTEM INFORMASI SEWA KAPAL BERBASIS VISUAL BASIC (VB) PADA PT. PELAYARAN DUTA LINTAS SAMUDERA CABANG SAMARINDA
}

\author{
Ita Arfyanti ${ }^{1)}$, Azahari Lathyf ${ }^{2)}$, Henny Afrida) \\ ${ }^{1,3}$ Sistem Informasi, Stmik Widya Cipta Dharma \\ ${ }^{2}$ Teknik Informatika, Stmik Widya Cipta Dharma \\ 1,2,3 J1. Prof. M. Yamin No. 25, Samarinda, 75123 \\ E-mail : qonita23@yahoo.com ${ }^{1)}$, azaharilathyf@yahoo.com ${ }^{2)}$, informatikawicida@gmail.com ${ }^{3)}$
}

\begin{abstract}
ABSTRAK
PT. Duta Lintas Samudera Samarinda adalah merupakan salah satu instansi yang bergerak dalam bidang jasa. Sampai saat ini pengolahan data Sewa Kapal masih dilakukan dengan cara manual dan menggunakan perangkat komputer dengan pengolahan data laporan menggunakan aplikasi Ms. Excel.

Metode yang digunakan pada penelitian ini meliputi metode pengumpulan data yaitu penelitian lapangan dan penelitian kepustakaan. Sedangkan metode pengembangan sistem yang digunakan dalam pengembangan sistem informasi ini adalah metode waterfall terdiri dari perencanaan sistem, analisis sistem, desain sistem, penerapan sistem, dan perawatan sistem. Dengan bantuan tools seperti flow of document (FOD), data flow document (DFD), hierarchy input proses output (HIPO), Dan Entiti Relation Of Documen (ERD), tstruktur database dan desain input output program.

Penelitian ini menghasilkan suatu Sistem Informasi Sewa Kapal Berbasis VB yang dapat Digunakan oleh Administrasi, Aktivitas yang dapat dilakukan dengan sistem ini meliputi penyewaan kapal, dan beberapa laporan.

Sistem ini dikembangkan dengan pemrograman Microsoft Visual Basic 6.0 dan databasenya dibangun dengan menggunakan MySQL, karena kebutuhan yang selalu berkembang, maka kekurangan pada sistem ini nantinya dapat diperbaiki pada pengembangan sistem selanjutnya.
\end{abstract}

Kata Kunci : Sistem, Informasi, Sewa Kapal Berbasis VB 6.0

\section{PENDAHULUAN}

Dengan semakin berkembangnya kebutuhan pengolahan data dan informasi, di dalam sebuah perusahaan dibutuhkan beberapa komputer yang digunakan oleh banyak orang yang bekerja dalam sebuah tim. Untuk saling bertukar data dan informasi, maka komputer-komputer yang digunakan akan terhubung antara satu dengan yang lainnya. Dengan mengerahkan pendayagunaan potensi sumber daya manusia secara baik dan optimal dalam pengelolaan sumber informasi dan komunikasi menunjukkan bahwa informasi dapat di implementasikan dalam dunia jasa transportasi.

PT. duta lintas samudera samarinda adalah merupakan salah satu instansi yang bergerak dalam bidang jasa. Sampai saat ini pengolahan data Sewa Kapal masih dilakukan dengan cara manual dan menggunakan perangkat komputer dengan pengolahan data laporan menggunakan aplikasi Ms. Excel.

Terdapat beberapa kendala dalam hal pengelolaan data sewa kapal pada PT. duta lintas samudera, seperti kesulitan dalam pencarian kapal, pencarian surat bukti pembayaran dan tidak terhubungnya antar komputer, hal tersebut membutuhkan waktu yang cukup lama.
Kesulitan-kesulitan tersebut membuat pekerjaan jadi tidak hemat waktu.

Dari latar belakang masalah tersebut, maka untuk membantu menyelesaikan permasalahan yang dihadapi, dibuatlah suatu sistem informasi sewa kapal berbasis visual basic (VB), yang mana nantinya diharapkan dapat mengatasi kendala-kendala yang ada dan dapat diterapkan dalam sistem kerja pada PT.Pelayaran Duta Lintas Samudera Cabang Samarinda Sebrang

\section{RUANG LINGKUP PENELITIAN}

Dalam penelitian ini permasalahan mencakup :

1. Cakupan Masalah

Terdapat beberapa kendala dalam hal pengelolaan data persediaan data penyewa kapal pada PT. Pelayaran Duta Lintas Samudera, seperti kesulitan dalam pencarian bukti Pembayaran, pencarian data kapal, data nakhoda,data aktivitas dan tidak terhubungnya antar komputer, hal tersebut membutuhkan waktu yang cukup lama. Kesulitan-kesulitan tersebut membuat pekerjaan jadi tidak hemat waktu. 
2. Batsan-batasan penelitian

1). Administrasi

Administrasi yaitu meliputi penginputan data kapal, data nakhoda data penyewa, data aktivitas, data bongkar batubara, data muat batubara, dan mencetak laporan atau bukti pembayaran

2). Pimpinan

Pimpinan sebagai pihak yang membutuhkan informasi hanya melihat beberapa output dari sistem tersebut yaitu laporan sewa kapal, laporan kapal, laporan nakhoda, laporan transaksi kapal,

1). Untuk membangun suatu Sistem Informasi Sewa Kapal Berbasis Visual Basic (VB) yang dimana suatu sistem tersebut dapat digunakan oleh Administasi Kantor demi kelancaran dalam kinerja.

2). Mempermudah staff Admin dalam pengolahan data sewa kapal, data nakhoda, dan data kapal

3). Membuat Sistem Informasi Sewa Kapal menjadi terkomputerisasi

4). Membuat basisdata sewa kapal.

\section{BAHAN DAN METODE}

\subsection{Penjelasan Bahan}

Sistem merupakan kumpulan elemen yang saling berkaitan yang bertanggungjawab memproses masukan (input) sehingga menghasilkan keluaran (output) (Kusrini, 2007)

MySQL tergolong sebagai DBMS (Database Management System). Perangkat lunak ini bermanfaat untuk mengelola data dengan cara yang sangat fleksibel dan cepat. (Kadir, 2009)

Visual Basic selain disebut sebagai bahasa pemrograman (Language Program), juga sering disebut sebagai sarana (Tool) untuk menghasilkan programprogram aplikasi berbasis Windows. (Yuswanto, 2003)

\subsection{Metode}

(Waterfall) adalah untuk membantu mengatasi kerumitan yang terjadi akibat proyek-proyek pengembangan perangkat lunak (Simarmata, 2010).

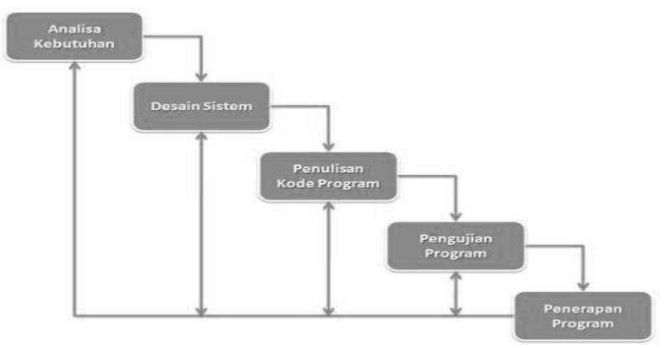

\section{Gambar 1. Waterfall}

\section{RANCANGAN SISTEM/APLIKASI}

1. Flow Of Document (FOD) Yang Berjalan

Flow Of Document (FOD) yang berjalan dimulai pada bagian administrasi yang pada bagian ini mengalirkan dokumen form isi sewa kapal ke Entitas Penyewa. Pada bagian Entitas Penyewa form tersebut diisi secara manual dan terbitlah dokumen yang telah terisi kemudian dialirkan lagi ke Entitas Administrasi untuk dilakukan proses sewa kapal secara manualisasi dan terbitlah daftar sewa kapal yang kemudian dialirkan ke proses pembuatan laporan. Pada Entitas Administrasi juga terdapat dokumen data kapal yang kemudian dialirkan ke proses pembuatan laporan. Proses pembuatan laporan dilakukan pada Entitas Administasi yang menerbitkan Laporan Daftar Kapal dan Laporan Sewa Kapal yang kemudian dialirkan ke Entitas Pimpinan. Proses selesai pada entitas pimpinan.

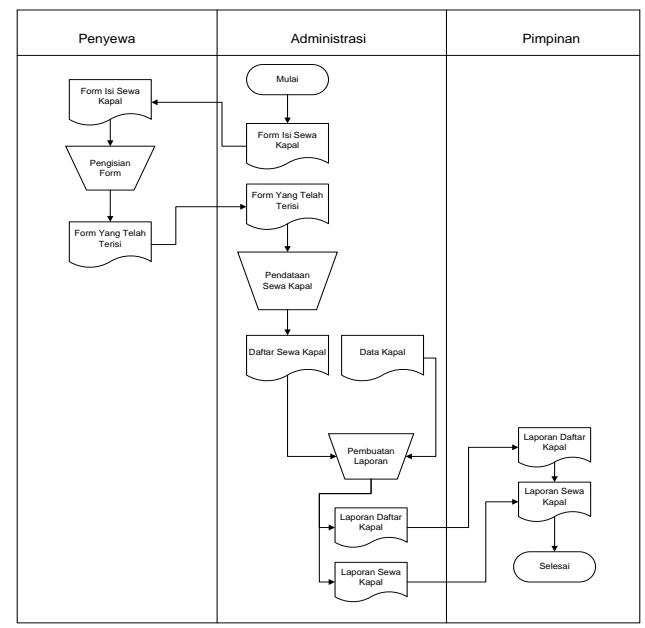

Gambar 2. FOD Yang Berjalan

\section{Flow Of Document (FOD) Yang Diusulkan}

Flow Of Document (FOD) yang diusulkan dimulai pada Entitas Administrasi yang pada entitas ini mengalirkan dokumen form isi sewa kapal ke Entitas Penyewa. Pada bagian Entitas Penyewa form tersebut diisi secara manual dan terbitlah dokumen yang telah terisi kemudian dialirkan lagi ke Entitas Administrasi untuk dilakukan penginputan sewa kapal lewat keyboard dan disimpan dalam data store penyewa yang diproses secara komputerisasi yang kemudian tersimpan dalam data store sewa kapal dan terbitlah daftar sewa kapal. Pada Entitas administrasi juga terdapat dokumen data kapal yang kemudian dilakukan penginputan data lewat keyboard dan disimpan dalam data store kapal kemudian diproses secara komputerisasi dan terbitlah daftar kapal. Selain itu pada Entitas Administrasi juga terdapat dokumen data nahkoda yang kemudian dilakukan penginputan data lewat keyboard dan disimpan dalam data store nahkoda kemudian diproses secara komputerisasi dan terbitlah daftar nahkoda. Proses pembuatan laporan dilakukan pada Entitas Administasi yang mendapat aliran data dari data store penyewaa, data store kapal, data store nahkoda dan data store sewa kapal yang menerbitkan Laporan Daftar kapal, laporan daftar penyewa, laporan daftar nahkoda dan laporan sewa kapal yang kemudian dialirkan ke Entitas Pimpinan. Proses selesai pada Entitas Pimpinan. 


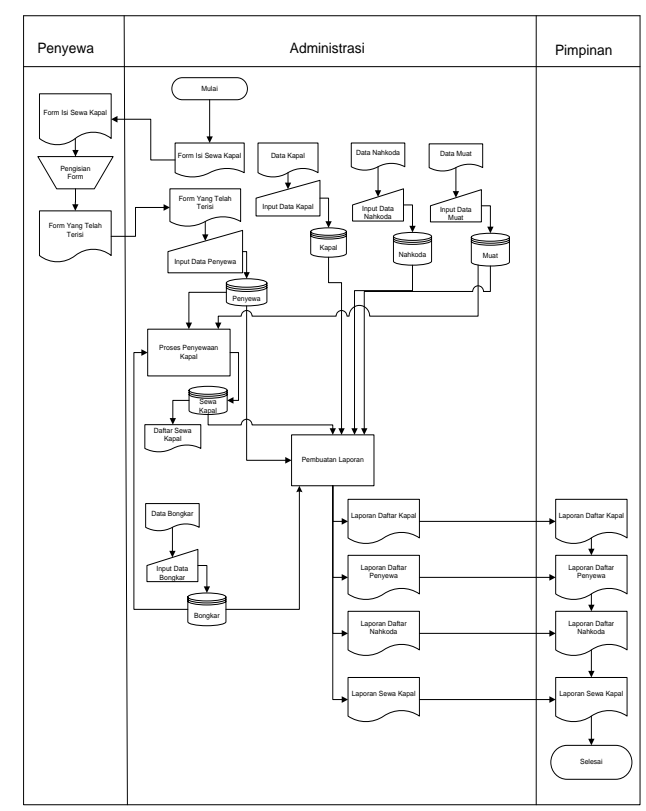

Gambar 3. FOD Yang Diusulkan

2 context Diagram

Pada gambar diatas terdapat 3 (Tiga) entitas, yaitu Entitas Penyewa yang memberikan data penyewa ke sistem. Entitas Bagian Administrasi memberikan data kapal, data nahkoda, data muat, data bongkar, data aktifitas kapal dan data sewa kapal ke sistem. Dan Entitas Bagian Pimpinan mendapatkan laporan daftar kapal, laporan daftar penyewa, laporan daftar nahkoda dan laporan sewa kapal.

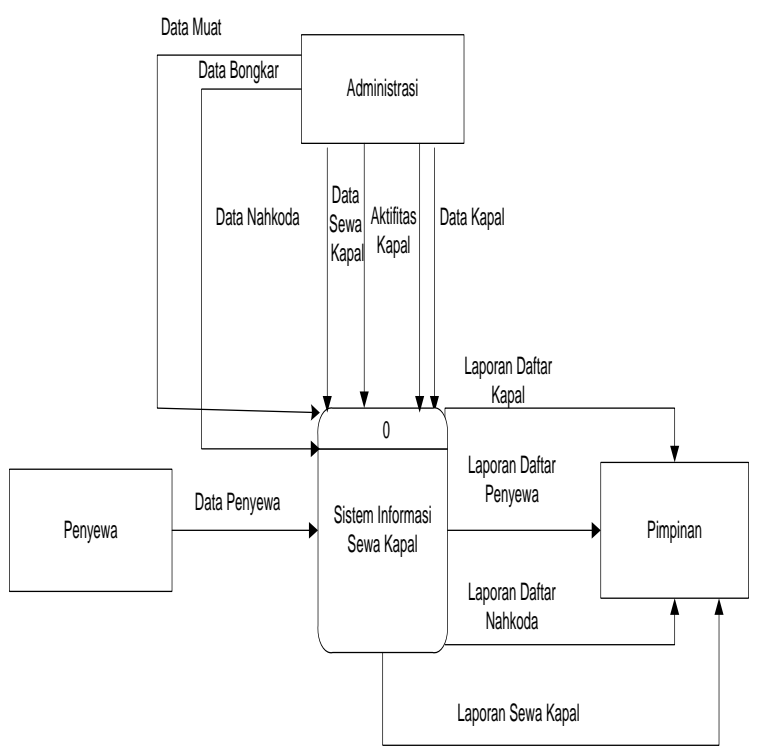

Gambar 4. Context Diagram

\section{Data Flow Diagram (DFD) Level 0}

DFD diatas Entitas Penyewa menjadi sumber data pengguna yang datanya disimpan dalam penyimpanan data (data store) penyewa. Entitas Administrasi menjadi sumber data kapal, data nahkoda dan data sewa kapal yang datanya disimpan dalam penyimpanan data (data store) kapal, data store nahkoda dan data store sewa kapal. Proses pembuatan laporan memperoleh data dari data store kapal, penyewa, nahkoda dan sewa kapal, dimana menghasilkan laporan daftar penyewa, laporan daftar kapal, laporan daftar nahkoda dan laporan sewa kapal yang dialirkan ke entitas pimpinan.

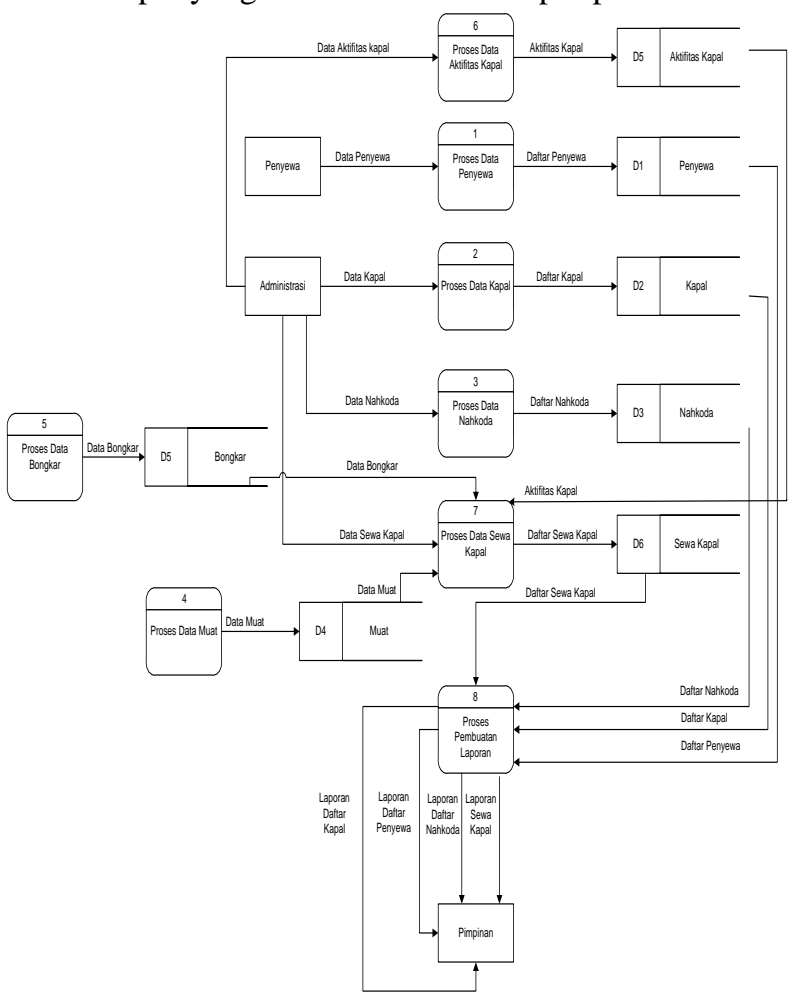

Gambar 5. Data Flow Diagram (DFD) Level 0

4.Data Flow Diagram (DFD) Level 1

DFD level 1 diatas dimulai dari data store penyewa yang menghasilkan laporan daftar penyewa yang kemudian dialirkan ke entitas pimpinan. Data store kapal yang menghasilkan laporan daftar kapal yang kemudian dialirkan ke entitas pimpinan. Data store nahkoda yang menghasilkan laporan daftar nahkoda yang kemudian dialirkan ke entitas pimpinan dan data store sewa kapal menghasilkan laporan daftar sewa kapal yang kemudian dialirkan ke entitas pimpinan.

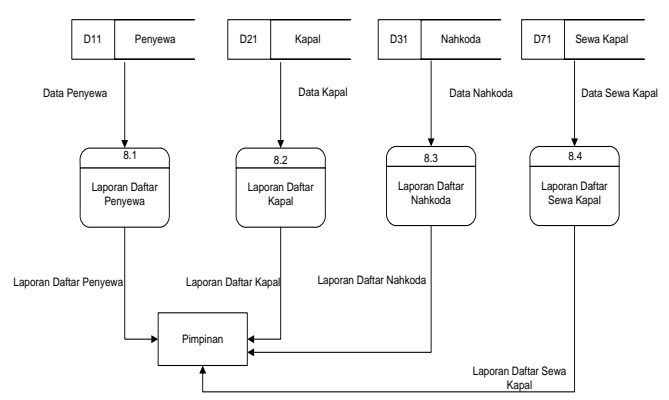

Gambar 6. Data Flow Diagram (DFD) Level 1 


\section{HIPO (Hirarchy Plus Input-Proses-Output)}

1. Data Penyewa, dimana dalam proses ini dilakukan penginputan data penyewa.

2. Data Kapal, dimana dalam proses ini dilakukan penginputan data kapal.

3. Data Nahkoda, dimana dalam proses ini dilakukan penginputan data nahkoda.

4. Data Muat, dimana dalam proses ini dilakukan penginputan data muat kapal

5. Data Bongkar, dimana dalam proses ini dilakukan penginputan data bongkar kapal

6. Data Aktifitas Kapal, dimana dalam proses ini dilakukan penginputan data aktifitas kapal.

7. Transaksi, dimana dalam proses ini dilakukan pemrosesan transaksi sewa kapal.

8. Proses pelaporan, dimana dalam proses ini dilakukan proses pelaporan daftar penyewa, daftar kapal, daftar nahkoda dan laporan sewa kapal.

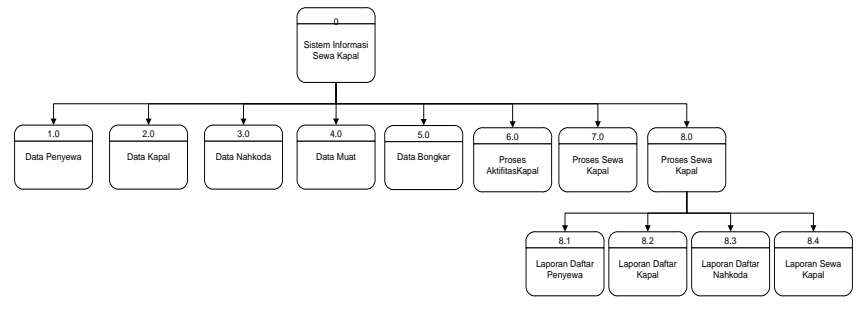

Gambar HIPO (Hirarchy Plus Input-Proses-output)

\section{ERD (Entity Relationsip Diagram)}

1. Setiap kapal memiliki lebih dari 1 nahkoda dan lebih dari 1 kapal memiliki aktifitas kapal.

2. Lebih dari 1 penyewa boleh melakukan penyewaan kapal dan lebih dari 1 kapal boleh disewa.

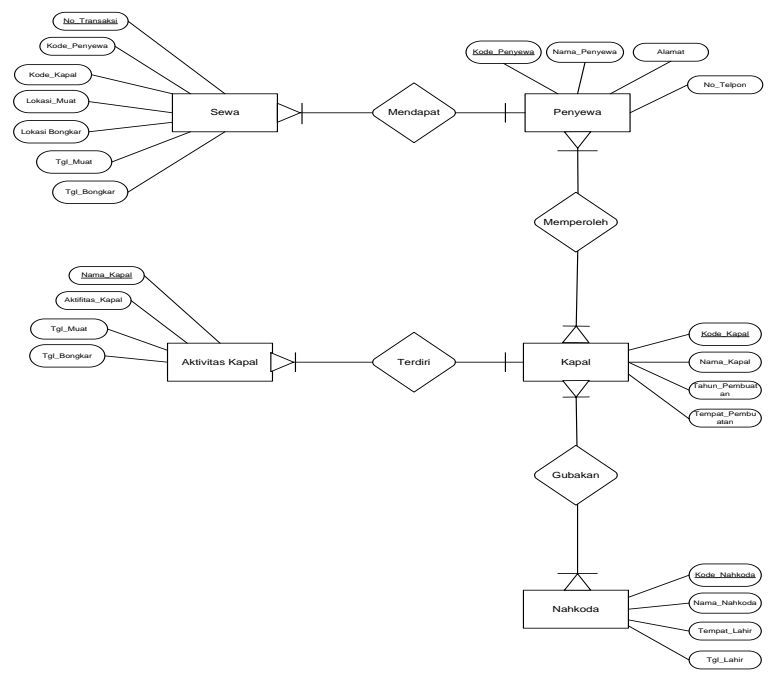

Gambar HIPO (Hirarchy Plus Input-Prosesoutput)

\section{IMPLEMENTASI}

1. tampilan Form Menu

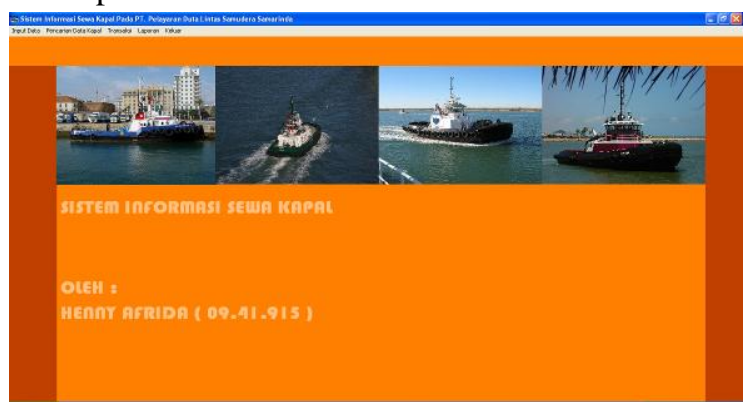

Gambar 7. Form Input Menu Sewa Kapal

Pada gambar 4.9 merupakan tampilan menu utama Sistem Informasi Penyewaan Kapal Tunda dan Ponton. Pada form tersebut terdapat 4 (empat) macam pilihan sistem yaitu:

1. Input Data, merupakan menu untuk menginput data kapal, data penyewa, data nahkoda, data muat, data bongkar dan data aktivitas.

2. Pencarian Data Kapal, merupakan menu untuk pencarian data kapal berdasarkan nama kapal dan aktifitas kapal.

3. Transaksi, merupakan menu untuk menginputkan transaksi sewa kapal

4. Laporan, merupakan menu untuk menampilkan daftar kapal, daftar sewa, daftar nahkoda dan laporan sewa kapal.

\section{Tampilan Form Input Data Kapal}

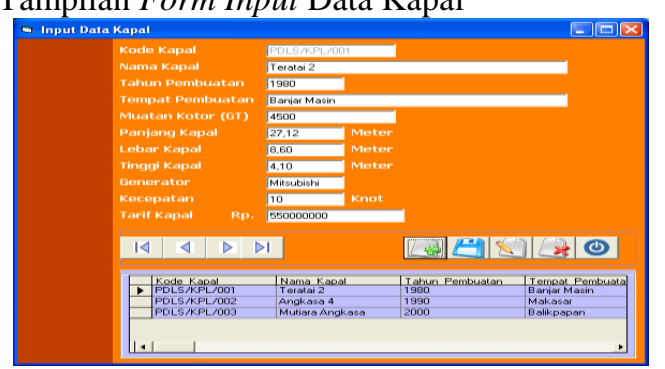

Gambar 2. Form Input Data Kapal

Pada gambar 4.10 merupakan form untuk menginputkan data kapal. Dimana terdiri dari beberapa inputan. yaitu kode kapal, nama kapal, tahun pembuatan, tempat pembuatan, muatan kotor, panjang kapal, lebar kapal, tinggi kapal, generator, kecepatan dan tarif kapal. Dalam tampilan input data ini terdapat 4 (empat) tombol navigasi dan 5 (lima) tombol lainnya yaitu tombol baru, simpan, edit, hapus dan keluar. Jika pengguna (user) menekan tombol baru maka pengguna (user) dapat meginputkan data yang baru. Jika pengguna (user) menekan tombol simpan maka data kapal yang telah di input akan tersimpan. Jika pengguna (user) menekan tombol edit maka kesalahan data kapal yang telah di input tadi dapat diperbaiki. Jika pengguna (user) menekan tombol hapus maka data kapal yang salah dapat dihapus. Apabila pengguna(user) menekan tombol keluar. Maka proses program akan kembali ke menu utama. 
3. TampilanTransaksi Data Penyewa

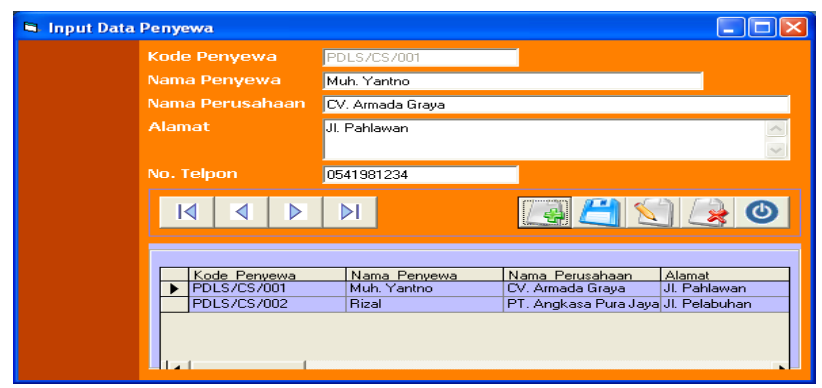

\section{Gambar 3 Tampilan Transaksi Data Penyewa}

Pada gambar 4.11 merupakan form untuk menginputkan data penyewa. Data yang akan diinput berisikan kode penyewa, nama penyewa, nama perusahaan, alamat dan no telpon. Dalam tampilan input data ini terdapat 4 (empat) tombol navigasi dan 5 (lima) tombol lainnya yaitu tombol baru, simpan, edit, hapus dan keluar. Jika pengguna (user) menekan tombol baru maka pengguna (user) dapat meginputkan data yang baru. Jika pengguna (user) menekan tombol simpan maka data penyewa yang telah di input akan tersimpan. Jika pengguna (user) menekan tombol edit maka kesalahan data penyewa yang telah di input tadi dapat diperbaiki. Jika pengguna (user) menekan tombol hapus maka data penyewa yang salah dapat dihapus. Apabila pengguna(user) menekan tombol keluar, maka proses program akan kembali ke menu utama.

\section{Tampilan Data Nahkoda}

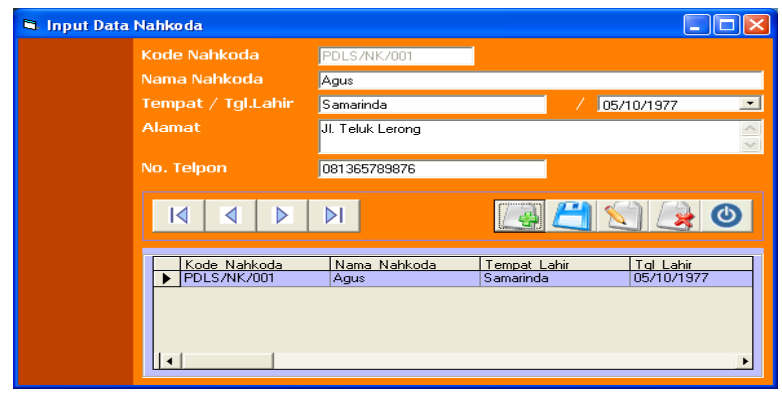

\section{Gambar 4 Tampilan Data Nahkoda}

Pada gambar 4.12 merupakan form untuk menginputkan data nahkoda. Data yang akan diinput berisikan kode nahkoda, nama nahkoda, tempat, tgl lahir, alamat dan no telpon. Dalam tampilan input data ini terdapat 4 (empat) tombol navigasi dan 5 (lima) tombol lainnya yaitu tombol baru, simpan, edit, hapus dan keluar. Jika pengguna (user) menekan tombol baru maka pengguna (user) dapat meginputkan data yang baru. Jika pengguna (user) menekan tombol simpan maka data nahkoda yang telah di input akan tersimpan. Jika pengguna (user) menekan tombol edit maka kesalahan data nahkoda yang telah di input tadi dapat diperbaiki. Jika pengguna (user) menekan tombol hapus maka data nahkoda yang salah dapat dihapus. Apabila pengguna(user) menekan tombol keluar, maka proses program akan kembali ke menu utama.

5.Tampilan Data Muat

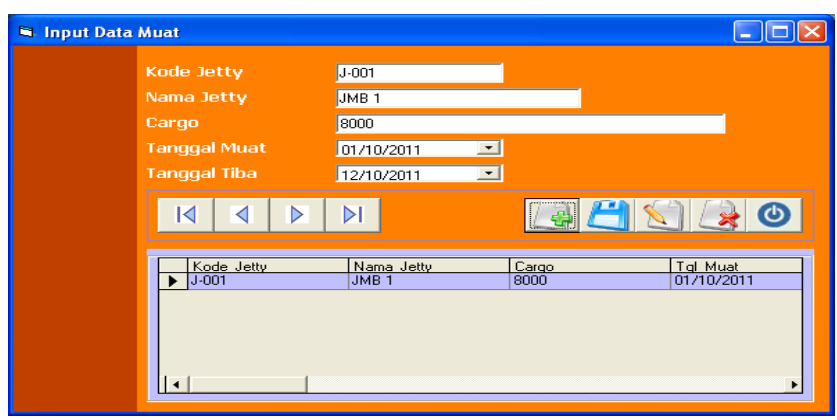

Gambar 4 Tampilan Data Muat

Pada gambar 4.13 merupakan form untuk menginputkan data muat. Data yang akan diinput berisikan nama jetty, cargo, tanggal tiba dan tanggal muat. Dalam tampilan input data ini terdapat 4 (empat) tombol navigasi dan 5 (lima) tombol lainnya yaitu tombol baru, simpan, edit, hapus dan keluar.Jika pengguna (user) menekan tombol baru maka pengguna (user) dapat meginputkan data yang baru. Jika pengguna (user) menekan tombol simpan maka data muat yang telah di input akan tersimpan. Jika pengguna (user) menekan tombol edit maka kesalahan data muat yang telah di input tadi dapat diperbaiki. Jika pengguna (user) menekan tombol hapus maka data muat yang salah dapat dihapus. Apabila pengguna(user) menekan tombol keluar, maka proses program akan kembali ke menu utama.

5. Tampilan Data Bongkar

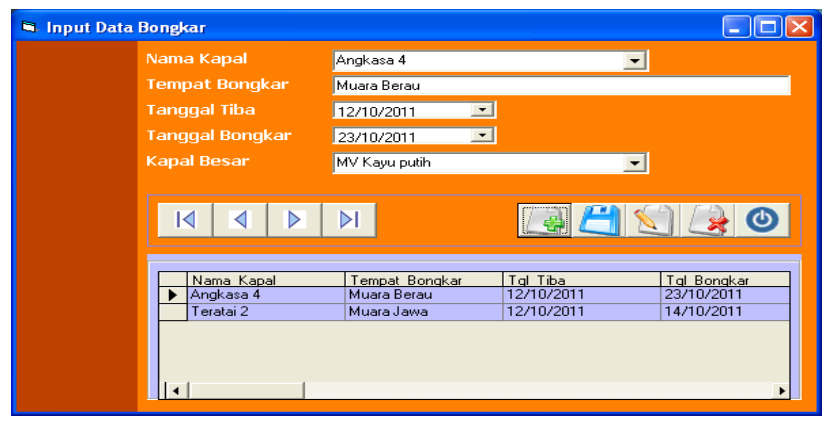

Gambar 5 Tampilan Data Bongkar

6. Tampilan Transaksi data Aktivitas Kapal

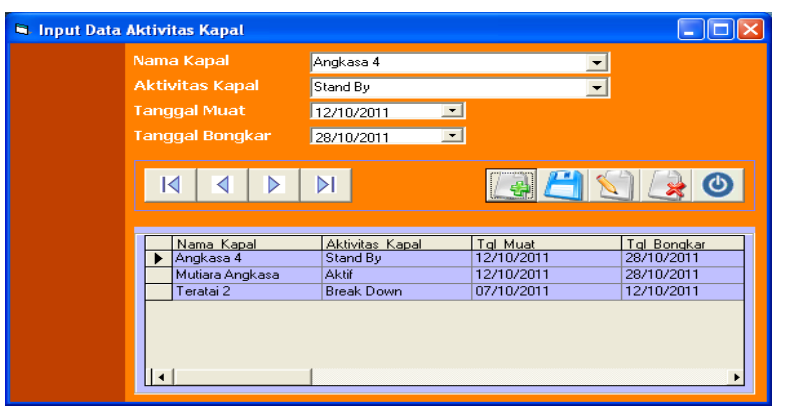

Gambar 6 Tampilan Transaksi Data Aktivitas Kapal 
Pada gambar 4.15 merupakan form untuk menginputkan data aktivitas kapal. Data yang akan diinput berisikan nama kapal, aktivitas kapal, tanggal muat dan tanggal bongkar. Dalam tampilan input data ini terdapat 4 (empat) tombol navigasi dan 5 (lima) tombol lainnya yaitu tombol baru, simpan, edit, hapus dan keluar Jika pengguna (user) menekan tombol baru maka pengguna (user) dapat meginputkan data yang baru. Jika pengguna (user) menekan tombol simpan maka data aktivitas kapal yang telah di input akan tersimpan. Jika pengguna (user) menekan tombol edit maka kesalahan data aktivitas kapal yang telah di input tadi dapat diperbaiki. Jika pengguna (user) menekan tombol hapus maka data aktivitas kapal yang salah dapat dihapus. Apabila pengguna(user) menekan tombol keluar, maka proses program akan kembali ke menu utama.

\section{Tampilan Pencarian Data Kapal}

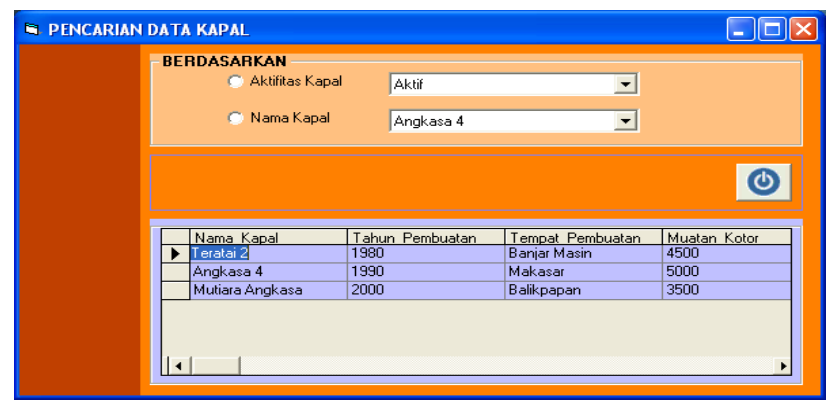

Gambar 7 Tampilan Pencarian Data Kapal

Pada gambar 4.16 merupakan form pencarian data kapal. Pencarian data kapal dapat dilakukan berdasarkan aktifitas kapal dan berdasarkan nama kapal. Apabila user ingin keluar dari form ini klik tombol tutup.

\section{Tampilan Transaksi Sewa Kapal}

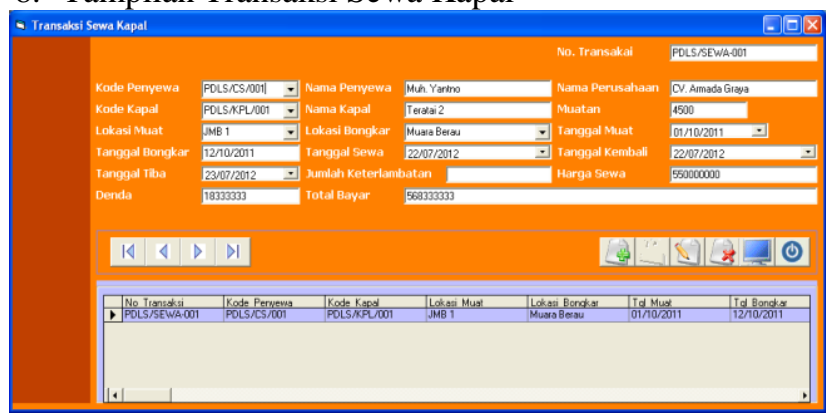

Gambar 8 TampilanTransaksi Sewa Kapal

Pada gambar 4.17 merupakan form untuk menginputkan transaksi sewa kapal. Data yang akan diinput berisikan no transaksi, kode penyewa, nama penyewa, nama perusahaan, kode kapal, nama kapal, muatan, lokasi muat, lokasi bongkar, tanggal muat, tanggal bongkar, tangal sewa, tanggal kembali, tanggal tiba, hari keterlambatan, harga sewa/ton, denda dan total bayar.. Dalam tampilan input data ini terdapat 4 (empat) tombol navigasi dan 5 (lima) tombol lainnya yaitu tombol baru, simpan, edit, hapus dan tutup. Jika pengguna (user) menekan tombol baru maka pengguna (user) dapat meginputkan data yang baru. Jika pengguna (user) menekan tombol simpan maka transaksi sewa kapal yang telah di input akan tersimpan. Jika pengguna (user) menekan tombol edit maka kesalahan transaksi sewa kapal yang telah di input tadi dapat diperbaiki. Jika pengguna (user) menekan tombol hapus maka transaksi sewa kapal yang salah dapat dihapus. Apabila pengguna(user) menekan tombol keluar, maka proses program akan kembali ke menu utama.

\section{KESIMPULAN}

1 Dengan adanya Sistem Informasi Sewa Kapal dan Ponton Pada PT. Pelayaran Duta Lintas Samudera Samarinda dengan menggunakan pemrograman visual basic 6.0, dapat mengefisiensikan waktu dalam proses penyimpanan data dokumentasi sewa kapal.

2 Sistem yang telah dibangun ini dapat mengetahui total harga penyewaan kapal dalam sebulan, pertahun, dan dapat mengetahui perusahaan siapa saja yang menyewa.

\section{SARAN}

1 Agar PT. Pelayaran Duta Lintas Samudera Samarinda khususnya bagian administrasi menunjuk operator khusus yang menjalankan sistem ini sehingga dapat terkonsentrasi pada satu kerjaan sehingga pelayanan akan lebih baik.

2 Agar PT. Pelayaran Duta Lintas Samudera Samarinda membuat koneksi jaringan komputer ke masing-masing bagian untuk memudahkan pengolahan data.

\section{DAFTAR PUSTAKA}

Director Jenderal Perhubungan Laut 2003, Konsep Dasar Perkapalan di Indonesia, Pelindo Jakatra.

G.R. Terry Organisasi Perusahaan, "balal Pustaka, :Jakarta 1994.

Jogiyanto, HM，2003, Analisis \& Disain Sistem Informasi pendekatan terstruktur teori dan praktek aplikasi bisnis, Andi Offset, Yogyakarta.

Jogiyanto, HM, 2003, Analisis \& Disain Sistem Informasi Andi Offset, Yogyakarta Kamus besar bahasa Indonesia, 2003, Balai Pustaka, Jakarta.

Jhanner Silalahi 2010, AP BP3IP STMT Trisakti angkatan X Kinerja Operasional, Blogspot .Com

Jogianto HM, 2009, Visual Basic sebagai alat kendali peralatan Elektronik, Penerbit, Andi Offset, Yogyakarta.

Kadir Abdul 2003, Pengenalan Sistem Informasi, Andi Offset,Yogyakarta.

Koesnoen 2009, Undang-Undang Hukum, KUHD Pasal 320. Jakarta. 